\title{
WPS3626
}

\section{Global Monetary Conditions versus Country-Specific Factors in the Determination of Emerging Market Debt Spreads}

\author{
Mansoor Dailami ${ }^{1}$ \\ Paul R. Masson ${ }^{2}$ \\ Jean Jose Padou ${ }^{3}$
}

\begin{abstract}
We offer evidence in this paper that US interest rate policy has an important influence in the determination of credit spreads on emerging market bonds over US benchmark treasuries, and therefore on their cost of capital. Our analysis improves upon the existing literature and understanding by addressing the dynamics of market expectations in shaping views on interest rate and monetary policy changes and by recognizing nonlinearities in the link between US interest rates and emerging market bond spreads, as the level of interest rates affects the market's perceived probability of default and the solvency of emerging market borrowers. For a country with a moderate level of debt, repayment prospects would remain good in the face of an increase in US interest rates, so there would be little increase in spreads. A country close to the borderline of solvency would face a steeper increase in spreads. Simulations of a 200 basis points (bps) increase in US short-term interest rates (ignoring any change in the US 10 year Treasury rate) show an increase in emerging market spreads ranging from 6 bps to 65 bps, depending on debt/GDP ratios.
\end{abstract}

World Bank Policy Research Working Paper 3626, June 2005

The Policy Research Working Paper Series disseminates the findings of work in progress to encourage the exchange of ideas about development issues. An objective of the series is to get the findings out quickly, even if the presentations are less than fully polished. The papers carry the names of the authors and should be cited accordingly. The findings, interpretations, and conclusions expressed in this paper are entirely those of the authors. They do not necessarily represent the view of the World Bank, its Executive Directors, or the countries they represent. Policy Research Working Papers are available online at http://econ.worldbank.org.

\footnotetext{
${ }^{1}$ World Bank, Development and Prospects Group.

${ }^{2}$ Rotman School of Management, University of Toronto

${ }^{3}$ University of Toronto
} 


\section{Introduction}

How interest rate policies in major industrial countries affect the pricing of emerging market debt remains an unresolved issue. Despite its very important policy and practical implications, our understanding of this link is shaped more by episodic evidence --in 1991, 1994, and 2003 when sharp swings in emerging market spreads coincided with a cyclical shift in the stance of US monetary policy --than by rigorous research and robust empirical findings. One point of view, popularized by the financial press, emphasizes the role of investors' risk tolerance or risk appetite, even though such factors are likely driven by a host of global macroeconomic conditions and uncertainties, including potentially the pace of changes in US interest rates, and are more directly relevant to the equity market than fixed income bond markets. And, while considerable literature exists on the determinants of emerging market debt spreads over US Treasury securities, that literature is disappointingly inconclusive concerning the effects of the global interest rate environment. For instance, Arora and Cerisola (2000), Min et al. (2003) and Ferrucci et al. (2004) find that the level of US interest rates plays a considerable role in the determination of emerging market bond spreads--spreads widen as US rates go up--but Kamin and von Kleist (1999) argue that there is little explanatory power of industrial country short-term interest rates, once one controls for credit quality. Eichengreen and Mody (2000), in contrast with all of the above, find that syndicated bank loans to emerging Market countries tend to respond positively to increases in US interest rates, and the spread on those loans responds negatively —-though this surprising result is very sensitive to regional differences. Furthermore, studies focusing on the US corporate bond market have also found a negative relationship between credit spreads and US Treasury 
yields (Longstaff and Schwartz, 1995; Duffee, 1996, and 1998; Colin-Dufresne, Goldstein, and Martin, 2001) ${ }^{4}$, as predicted by structural models of credit risk following Merton (1974).

Existing studies of the link between US interest rates and emerging market bond market spreads have several weaknesses. One major shortcoming is the scant attention paid to the dynamics of market expectations in shaping views on interest rate and monetary policy changes, and how such policy changes are factored into the determination of bond market prices and yields ${ }^{5}$. The hypothesis advanced here is that the market anticipates the future behavior of the Fed by observing the evolution of relevant leading short-term macroeconomic indicators and factors in such expectations well in advance of actual changes in interest rates. This dynamic induces an important correlation between emerging market bond spreads and key indicators of the US economic outlook such as the US non-farm payrolls report and retail sales, as is clearly demonstrated by recent experience--much of the market reaction regarding the bond spreads occurred in April/May 2004, when the reported payroll figures indicated stronger growth momentum than anticipated by the market ${ }^{6}$. The reason for this dynamic is the particular institutional setting of interest rates in the US, where under the prevailing regime (which in many ways is equivalent to inflation targeting, without an explicit target), the market comes to form views about Fed behavior, based on the evolution of

\footnotetext{
${ }^{4}$ Also studies by Leake (2003), and Boss and Scheicher (2002) focusing respectively on the UK and Euro-corporate bond markets, find a small negative relationship between credit spreads on sterling investment-grade corporate bonds and the level and slope of the term structure of UK interest rates.

${ }^{5}$ Arora and Cerisola (2000) however look at the predictability of US monetary policy, and find that heightened uncertainty about that policy leads to a widening of spreads.

${ }^{6}$ As Uribe and Yue (2003) note, US interest rates also help to drive business cycles in EM economies, and spreads respond to EM activity. However, their empirical results show that US interest rate shocks affect domestic EM variables mostly through their effects on country spreads.
} 
certain leading short-term economic indicators, such as payroll figures, retail sales, and core inflation data ${ }^{7}$.

A second weakness of the existing literature is the lack of attention paid to the non-linearity in the relationship between US interest rates and emerging market spreads. Indeed, the spread incorporates a default probability in a non-linear way, and the effect of higher world interest rates itself affects the default probability non-linearly. For instance, at low rates of interest and in periods of favorable economic activity and low debt in developing countries, a rise in US interest rates may have little effect on investors’ estimates of the probability of repaying - and indeed, on the objective likelihood of that repayment. In contrast, when the emerging market borrower is at the borderline of its ability to repay, a given increase in US rates may push the borrower over the edge, sharply increasing the probability of default. Such a scenario may have occurred, for instance, in 1982 and 1994.

A further aspect of that non-linearity is that sharp shifts of expectations of default probabilities may be self-fulfilling, and correspond to jumps between multiple equilibria. Indeed, those expectations can be rational because higher interest rates will increase the likelihood that countries cannot meet their debt service obligations. While models with sunspot equilibria are sometimes criticized as just adding an extra indeterminacy because what triggers the jumps between equilibria is not explained, in international capital markets, that role may be assumed by global liquidity conditions and the "appetite for risk.” In our estimation, we divide the sample into crisis and non-crisis periods. We also

\footnotetext{
${ }^{7}$ This accords with the view and assessment of key market practitioners. A credit market strategist was quoted by Credit (2004) as saying, "it is not the rate hikes that matter, but what is happening to the economy".
} 
include proxies for international liquidity and for contagion in financial markets. Indeed, given that there are investors in emerging market bonds that are common across countries, it is natural to expect that a crisis in one country should be associated with higher spreads in other markets, if they both are the result of a changed attitude to risk or liquidity.

A third improvement relative to the current literature is our use of more recent data (until June, 2004)—and longer time series; this may help to distinguish between hypotheses. In particular, we use monthly data for individual country emerging market Bond Index Plus $\left(\mathrm{EMBI}^{+}\right)$spreads, available from JP Morgan which is a major dealer in emerging bond markets, and extending back for some countries to 1991. The bonds are issued in US dollars, so that spreads reflect credit risk—-the probability that the borrower will not repay. The set of countries includes all the major sovereign borrowers, and the data are based on trading in secondary markets of Brady bonds and Eurodollar issues. Our sample includes the following 17 countries: Argentina, Brazil, Bulgaria, Colombia, Ecuador, Mexico, Morocco, Nigeria, Panama, Peru, the Philippines, Poland, Russia, South Africa, Turkey, Ukraine, and Venezuela. We estimate an unbalanced panel, with data availability varying from country to country. While the data on spreads are based on secondary market data, they provide many more data points and allow a finer appreciation of the effects of interest rate increases than primary market data. Moreover with transaction volumes in secondary markets surpassing those in primary markets by several fold, spreads based on secondary market prices are more informative and less contaminated by supply effects than the spreads for new issues. 


\section{A Framework for Analysis}

Our approach to understanding the link between US interest rates and emerging market debt spreads focuses on the impact of interest rates on the market's perceived probability of default. The starting point here is the simple relationship between the probability of default $p$ on emerging market bonds and the rate of interest on riskless securities, say US, paying rate $r$ (see, for instance, Arora and Cerisola, 2000). If the default is complete (with no repayment of either principal or interest ${ }^{8}$ ), investors are risk neutral, and assuming away the possibility of default correlation across borrowers, then the interest rate $i$ on emerging market bonds should yield the same expected return as US Treasuries, so

$$
1+r=(1+i)(1-p)+p \cdot 0
$$

Therefore, the spread $S$ over US Treasuries can be written

$$
S=i-r=(1+r) \frac{p}{1-p}
$$

or, in log form,

$$
\log S=\log (1+r)+\log \frac{p}{1-p}
$$

\footnotetext{
${ }^{8}$ In studies where default is taken to be less than complete, the rate of recovery upon default is generally assumed to be constant (see for instance, Elton et al. 2001).A constant recovery rate does not change our main results.
} 
We go behind this simple relationship to look at the determinants of the ability to service the debt ${ }^{9}$, while leaving aside issues of voluntary default. Suppose that the EM sovereign borrower has a stochastic income stream $Y$, and that it defaults when that income is less than the debt service. Then the probability of default will be given by

$$
p=\operatorname{Pr}[Y<i D]=\operatorname{Pr}\left[Y<\left(r+(1+r) \frac{p}{1-p}\right) D\right]
$$

We will further assume for concreteness that $Y$ is determined by a first order autoregression $Y=\rho Y_{-1}+\varepsilon$ with innovations that are i.i.d. with distribution function $F()$. Let $Z=r D-\rho Y_{-1}$ be the interest burden at a zero default probability minus expected income. Then the probability of default can be written

$$
p=\operatorname{Pr}\left[\varepsilon<Z+(1+r) \frac{p}{1-p} D\right]=F\left[Z+(1+r) \frac{p}{1-p} D\right]
$$

It is important to note three things about the above equation: i) the probability depends on the stock of debt, as well as lagged income; ii) equation (4) is highly nonlinear in the default probability; and iii) it can have multiple solutions, since, in general, the right hand side is increasing in the default probability ${ }^{10}$. Figure 1 shows the case where there are 3 intersections of the 45 degree line (the LHS of eq. 4) and the RHS of the equation.

\footnotetext{
${ }^{9}$ A seminal article is Eaton and Gersovitz (1981).

${ }^{10}$ See Jeanne (1997).
} 
Figure 1. Multiple Solutions for Default Probabilities

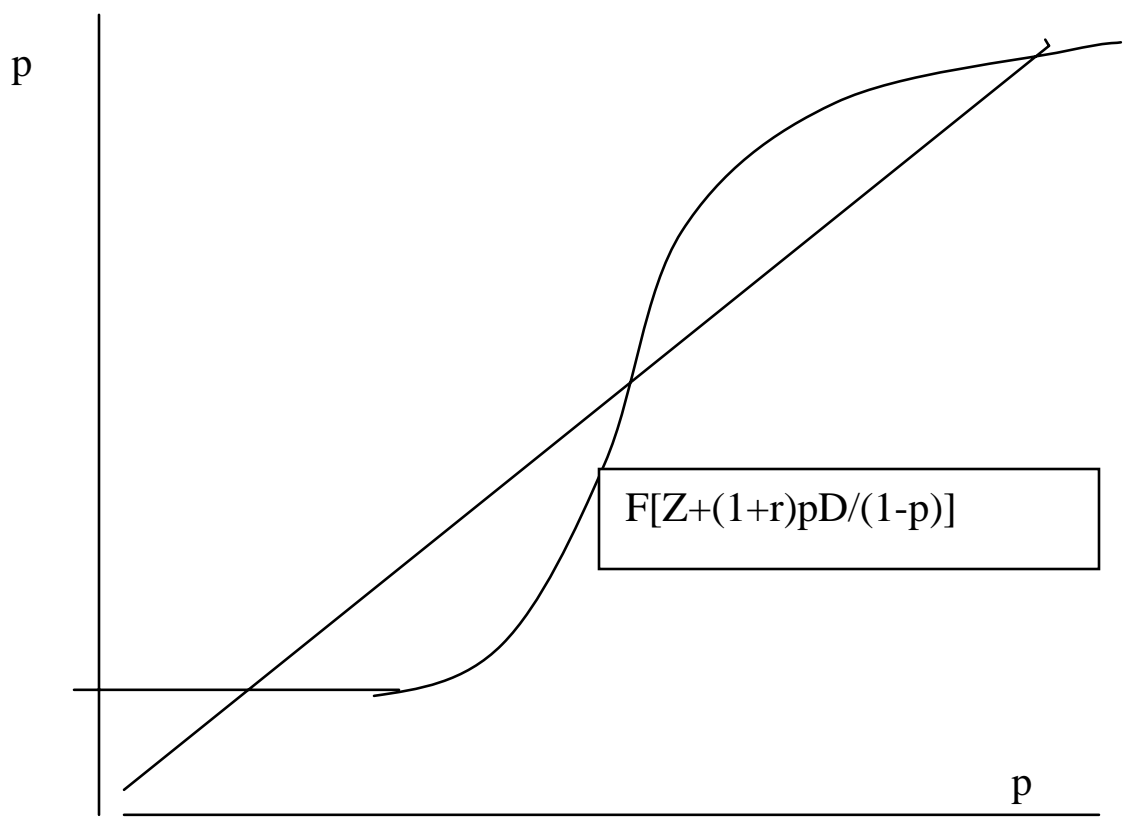

The intuition is clear: by expecting a default, investors can make a default more likely. However, this is only true in certain ranges for the variables and the parameters. The “fundamental” variable $\mathrm{Z}$ needs to be in a certain range, and, in particular, debt $D$ has to be large enough that increases in interest costs can make debt service painful for the emerging market borrower. A necessary condition for three solutions is that the cumulative distribution function should have a slope greater than unity at some point-in particular, at the middle intersection. Since the slope of this curve is simply the probability density function $f(x)=F^{\prime}(x)$, it is straightforward to show that this condition requires that

$$
f\left[Z+(1+r) \frac{p}{1-p} D\right] \cdot \frac{1+r}{(1-p)^{2}} D>1
$$

at the middle intersection point. 
What is the effect of increasing the US interest rate on the probability of default? Increasing the US rate shifts up the curve that corresponds to the RHS of (4): it increases the value of $p$ corresponding to the leftmost and the rightmost intersections - that is, increases the default probabilities. It has the opposite effect on the middle intersection, but, as in most models, that intersection is unstable, so it can be ignored. In addition to increasing the value of $p$ at the intersection points, it may also eliminate the two leftmost intersections, leaving only the third one, with the highest probability of default. Thus, if it shifts the curve up enough it may have a dramatic effect on the (rationally expected) occurrence of default, since the upper equilibrium makes a default very likely.

Let us then examine how increases in the US interest rate would affect the spread. From (2.a),

$$
\frac{d \log S}{d r}=\frac{1}{1+r}+\frac{1}{p(1-p)} \frac{d p}{d r}
$$

We see that, since $d p / d r>0$, both terms on the right hand side of (6) are positive, so that increases in US rates increase the spread. In addition to the non-linearity embodied in $d p / d r$, the derivative $d \log S / d r$ is also highly non-linear in $p$. A given change in the probability of default $d p / d r$ will have a larger effect on the spread when probabilities of default are either very low or high than when they are close to one-half.

The implications of the above for developing a more rigorous estimation methodology are two-fold. First, it is not sufficient just to include the US interest rate in a linear regression explaining the spread. The effect on the spread is non-linear, and depends on other variables. The time series of correlations of EMBI spreads with US interest rates (measured over 36 month rolling periods between December 1992 and June 
2004 ) show a great deal of fluctuation, with a clear break between crisis and non-crisis periods (Figures 2 and 3).Thus interacting US interest rate variables with variables which capture the severity of the debt problem may be essential to capturing the effect of global monetary conditions on emerging market spreads.

Figure 2. Correlation of EMBI and US interest rates rolling three-year periods. Dec 1995-Aug 2004

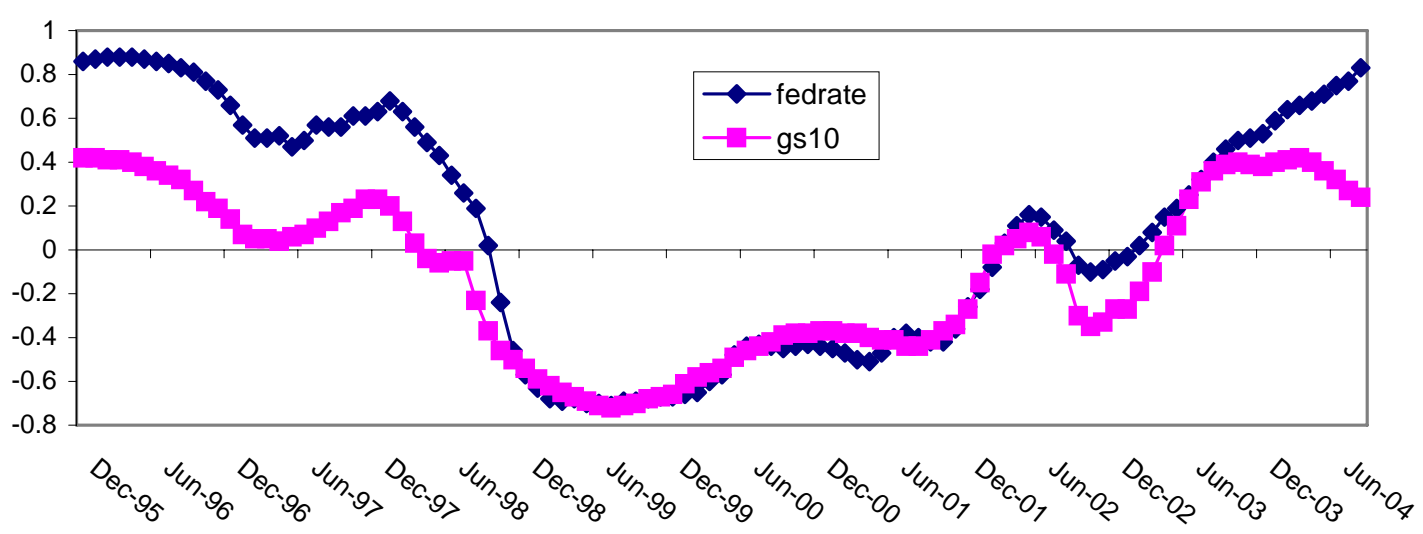

Figure 3 Correlation of EMBI and US interest rates rolling three-year periods Dec 1995-Aug 2004

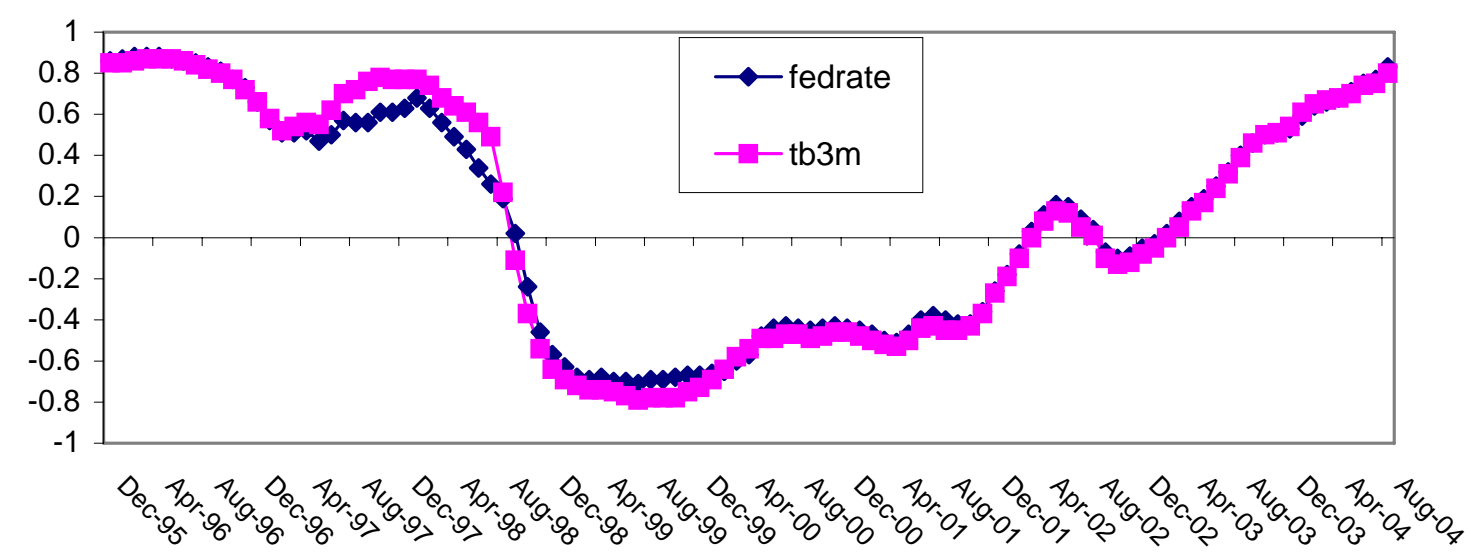

Second, the possibility of multiple equilibria should be taken into account. We see this possibility as being related to changes in global liquidity conditions and the 
appetite for risk, and hence we introduce variables that attempt to capture those features in regressions explaining the spreads. In addition, it may well be the case that the effect of explanatory variables on the spreads is different, depending on which equilibrium is chosen. Thus, it may make sense to divide the sample into two sub-samples: "normal" times, and “crisis” periods when a particular country faces sharply higher spreads as a result of a debt default or currency attack. For instance, it seems plausible that if a country is in crisis, then the effect of world monetary conditions on the spread will be less significant. It is likely that the country can emerge from crisis and reduce the very high interest rates that it faces mainly by its own actions-unless the crisis was provoked by a shift in global risk appetite (see next paragraph). In normal times, however, countries’ spreads may be very sensitive to the conditions in global capital markets, especially if they are in a middle region of high but not overwhelming debt. Dividing the sample would prevent outliers from distorting estimates of the influence of "push" factors. The occurrences of very high spreads in our sample are mostly associated with defaults or currency crises on the part of the borrowing country: Mexico in December 1994, Russia in August 1998, and Argentina in February 2002, for instance.

Moreover, the existence of multiple equilibria gives a natural role to contagion effects in international capital markets ${ }^{11}$. Again, this contagion may operate through a change in global risk appetite, and in our model, be signaled by changes in the spread between US corporate borrowers with high and low risk. It may also be evidenced by a

\footnotetext{
${ }^{11}$ For a discussion of the relationship between multiple equilibria and contagion, see Masson (1999; 2001). A contrary view of the relevance of multiple equilibria in financial markets is presented by Morris and Shin (1998; 2002). However, their argument relies on the iterated elimination of all dominated strategies (with infinite iteration), which experimental evidence suggests does not apply in real world situations (Camerer, 1997).
} 
positive effect of the spread in non-crisis countries of a dummy variable that counts the number of other countries in the crisis state. This could be expected to operate if the country itself is not in crisis; for the same reason as above, once a country is in the crisis state it is mainly affected by its own variables—or, if the crisis was caused by a loss of risk appetite, by an abatement of contagion and a return to more normal conditions.

\section{Empirical Methodology}

As in much of the empirical literature, we use panel regressions of the emerging market interest rate spread over US treasuries on domestic determinants of a country's credit-worthiness as well as global variables that explain the supply and cost of credit to emerging market. Ferrucci et al. (2004) call the first set of variables "pull factors”, and the second, "push factors"; their research concludes that both sets are important in explaining EM spreads. However, as the discussion above suggests, it is difficult to separate the two sets of variables conceptually. For instance, the level of US interest rates influences a country's creditworthiness since borrowing that is sustainable in a low world interest rate environment (whatever the country's economic fundamentals) may not be so when interest rates are high.

We follow Ferrucci et al. (2004) in distinguishing between long run influences on spreads, which are constrained to have the same coefficients for all countries, with the short run dynamics that can vary from country to country and may include other explanatory variables. The short-run dynamics are specified to take the form of an error correction model, where the errors are deviations from the long-run equilibrium relationship. 
The econometrics behind this model in a panel context are described in Pesaran, Shin, and Smith (1999). The model is estimated using their Pooled Mean Group Estimator. In particular, we posit a long run relationship linking the log of spreads of EM interest rates over comparable US Treasuries, to US interest rates, the spread between high and low risk US corporate bonds, and various variables reflecting the borrower's creditworthiness (trade openness, debt/income, the ratio of short-term debt in the total, and reserves/debt). If we call all these right hand side variables the vector $X$, then the long-run relationship is

$$
\log S_{i t}=\alpha_{i}+\sum_{j} \beta_{j} X_{i j t}
$$

where the intercept term may vary across countries, allowing for fixed effects, while the slope coefficients are constrained to be the same. The dynamic equations take the form error-correction models for which the short-run adjustment toward the same long-run relationship can vary across countries:

$$
\Delta \log S_{i t}=\phi_{i}\left[\alpha_{i}+\sum_{j} \beta_{j} X_{i j t-1}-\log S_{i t-1}\right]+\gamma_{i} \Delta Y_{i t}
$$

The vector $\Delta Y$ may include first differences of all or a subset of the $X$ variables, plus other variables that influence the short run dynamics but not the long-term equilibrium level of spreads. In the latter category we include current changes in US monetary policy variables and forecasts of their future evolution (to be described below). 
Note that the estimation of (8) is not straightforward using panel estimation programs, because of the non-linear constraints on the long run coefficients. In particular, if we estimate

$$
\Delta \log S_{i t}=\alpha_{i}+\sum_{j} b_{i j} X_{i j t}+c_{i} \log S_{i t-1}+d_{i} \Delta Y_{i t}+u_{i}
$$

then we need to impose the following constraints

$$
\frac{b_{i j}}{b_{k j}}=\frac{c_{i}}{c_{k}} \forall i, j, k
$$

Estimation can be done in two stages, that is, first estimate the long term regression, (7), and then use the lagged residuals to replace the term in square brackets in (8). We use the two-stage approach for our exploratory regressions that aim to narrow down the set of explanatory variables. However, this method is inefficient since it ignores the effect of short-term dynamics when estimating the long-term coefficients $\beta$. Therefore, the PMG estimates impose long-run coefficients in the context of a dynamic panel regression.

When considering variables that may influence short-run dynamics, we include changes in the above long-run determinants and also forecasts of the change in stance of US monetary policy. Thus we first estimate forecasting equations for US interest rates that include as explanatory variables lagged changes in US capacity utilization, retail sales, the producer price index, and M2 data. Then we test whether these forecasts have an additional effect, over and above the long run relationship between US interest rates and emerging market spreads and the contemporaneous change in US rates. 
In order to maximize the number of observations, and focus on the macroeconomic determinants of US monetary policy, we estimate the model at a monthly frequency, even if this limits the availability of country-specific determinants of emerging market credit-worthiness. For many of the countries in our sample, data on consumer prices, reserves and the money supply are available monthly, while quarterly or annual data are available for GDP and foreign debt. We interpolate the latter variables where necessary.

In specifying the effects of US monetary policy, we include in the long-run relationship the levels of US short rates (the US Treasury bill rate ${ }^{12}$ ), the 10 -year Treasury bond rate, and the interest rate spread between high and low risk US corporate bonds. The latter variables, as well as being influenced by US monetary policy, may also capture global risk appetite. We interact the US T Bill rate with the country’s debt to GNI ratio, since as discussed in section II, non-linearities are likely to be important. We have argued that it is important to divide the sample into crisis and non-crisis periods. A country $i$ is in a non-crisis period $t$ if in that period it is not suffering a crisis, even if other countries are. But it is also possible that the existence of crises at $t$ in other countries — and their number — may increase the interest rate for country i. A significant coefficient on the number of other countries in crisis may be evidence of contagion effects, since, if positive, it would come over and above the country's own fundamentals and global monetary conditions. ${ }^{13}$

\footnotetext{
${ }^{12}$ Arora and Cerisola (2000) suggest that the federal funds rate is more appropriate, but we find the TB rate to be a better explanatory variable of EM spreads.

${ }^{13}$ Eichengreen, Rose and Wyplosz (1995) find that the occurrence of crises elsewhere tends to increase a country's likelihood to experience a crisis.
} 
Dating of crisis periods is not straightforward, however. One approach is to let the data on exchange market pressure (the sum of exchange rate changes and reserve changes, appropriately weighted) identify crisis periods. A recent application is Kaminsky (2003), and we use the crisis dates she identifies (Kaminsky, 2003, table 2), but instead of assuming that the duration of each crisis is 24 months, we use a much smaller window, six months following the crisis date in her list-except for Argentina. In practice, the period of very high spreads has been limited to a few months, when a resolution has been in sight. Argentina’s 2002 default is an exception, and we make the crisis dummy continue to the end of our sample. We also add the Russian crisis, starting in August 1998, since Russia is not in her sample.

\section{Estimation Results}

We first describe the long-run (static) regressions of the log of spreads on both push and pull factors. Of especial interest is the relative importance of the two sets, and evidence of non-linearity in the relationship. Table 1 gives the coefficient estimates, with the sample divided into crisis and non-crisis periods, with the latter dominating in our sample (1497 months versus only 54 crisis periods $^{14}$ ).

Country specific variables seem to dominate US interest rates in influence over emerging market spreads. In particular, trade openness has a strong negative effect on spreads, which is plausible since more open countries are better able to adjust their

\footnotetext{
${ }^{14}$ As noted above, our choice of a small crisis window (6 months) limits the number of crisis periods. In addition, our reliance on Kaminsky (2003) for the crisis dates no doubt misses some crises, since not all the countries in our sample are on her list.
} 
Table 1. Long-Term Influences on Emerging Market Spreads, 1991M1-2004M6 ${ }^{15}$

Coefficient values (absolute t-ratios)

\begin{tabular}{|c|c|c|c|c|}
\hline explanatory variables & $\begin{array}{l}\text { full sample } \\
\text { (1) }\end{array}$ & $\begin{array}{l}\text { crisis periods } \\
\text { (2) }\end{array}$ & $\begin{array}{l}\text { non-crisis periods } \\
\text { (3) }\end{array}$ & $\begin{array}{c}\text { non-crisis } \\
\text { periods } \\
(4)\end{array}$ \\
\hline \multicolumn{5}{|l|}{ (1) US variables } \\
\hline long-term interest rate & $-.0192(0.94)$ & $.2261(1.18)$ & $-.0143(.74)$ & 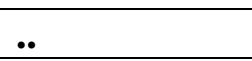 \\
\hline $\begin{array}{l}\text { hi-low corporate } \\
\text { spread }\end{array}$ & $.0739(9.08)$ & $.0601(0.57)$ & $.0794(10.0)$ & $.0796(12.4)$ \\
\hline \multicolumn{5}{|l|}{$\begin{array}{l}\text { (2) country specific } \\
\text { variables }\end{array}$} \\
\hline trade openness & $-.9260(24.2)$ & $-.0640(.08)$ & $-.918(23.6)$ & $-.913(23.9)$ \\
\hline debt/gni & $.0093(7.75)$ & $.0200(2.82)$ & $.0087(7.77)$ & $.0089(8.09)$ \\
\hline reserves/debt & $-.0212(15.9)$ & $-.0622(8.01)$ & $-.0194(16.0)$ & $-.0191(16.0)$ \\
\hline short-term/total debt & $-.0291(19.8)$ & $-.1055(4.37)$ & $-.0283(20.2)$ & $-.0280(20.1)$ \\
\hline \multicolumn{5}{|l|}{$\begin{array}{l}\text { (3) interaction } \\
\text { variables }\end{array}$} \\
\hline $\begin{array}{l}\text { US Tbill rate times } \\
\text { country's debt/gni }\end{array}$ & $.00066(3.21)$ & $.0011(0.69)$ & $.00084(4.31)$ & $.00081(4.35)$ \\
\hline contagion dummy & $.0115(1.20)$ & $-.2123(2.56)$ & .0186(1.97) & .. \\
\hline constant & $6.944(37.5)$ & 7.213(6.36) & $6.779(38.9)$ & $6.707(89.1)$ \\
\hline \multicolumn{5}{|l|}{ (4) statistics } \\
\hline no. of obs. & 1551 & 54 & 1497 & 1497 \\
\hline R2 & .5785 & .8243 & .5976 & .5960 \\
\hline p-value for zero coeffs & .0000 & .0000 & .0000 & .0000 \\
\hline
\end{tabular}

\footnotetext{
${ }^{15}$ Period of estimation depends on the country's data availability. Static regression of the log of spreads on the explanatory variables listed above, with all coefficients constrained to be the same for all countries.
} 
balance of payments in order to generate earnings to service external debt; this variable may also reflect the finding in the growth literature that more open countries tend to grow faster. As expected, the level of debt to a country's income has a significant positive influence on the spread it faces, while the reserves/debt ratio and the proportion of shortterm debt both have a significant negative influence. The latter effect may simply reflect an upward-sloping term structure.

Turning to the US interest rate variables, in non-crisis periods the US short-term rate, entered linearly, did not have a significant coefficient (not reported), while the longterm interest rate (reported here) has a negative, but insignificant, coefficient. These results contrast with those of Ferrucci et al. (2004). However, the interest rate spread on high-risk versus low-risk US corporate borrowers comes in very strongly in non-crisis periods.

As we have argued above, the effect of US rates can be expected to be non-linear, and the US Treasury bill rate interacted with the borrowing country's debt/gni ratio does in fact enter significantly in non-crisis periods (column 3) and produces significantly higher explanatory power than the interest rate entered alone. Thus, the impact of rising US rates is higher, the higher is a country's level of indebtedness. In non-crisis periods, countries are also vulnerable to crises in other countries, as the contagion dummy (the number of crises elsewhere) has a significant positive effect.

The relationship between global monetary conditions and the emerging market spread is quite different during periods of crisis, as we can see from column 2 of the table. A chi-square test rejects equality of the two sets of coefficients. In crisis periods 
the US Hi-low spread and the US Treasury bill rate interacted with a country's debt have no significant effect, as is also the case for the US long rate (which was already true in non-crisis periods). In contrast, all the "pull” factors except trade openness continue to have a significant influence on emerging market spreads in the expected direction. Somewhat surprisingly, the contagion dummy (that is, the number of other countries in crisis) has no longer a positive effect on spreads - it is the reverse; conditioned on a country being in crisis, its spreads do not suffer from other countries also being in crisis. Of course, the fact of being in a crisis situation may itself depend on the contagion dummy. It is also true that the constant term is significantly higher in column 2 than in column 3. In sum, it seems that interest rates charged to crisis countries are more dependent on their own behavior than on conditions on global capital markets.

When the crisis and non-crisis periods are pooled (column 1), not surprisingly the estimates resemble those of column 3, given the preponderance of non-crisis observations. However, the contagion dummy is now insignificant, and the explained variance is lower than for either sub sample. Since equality of the two sets of coefficients in the sub-samples is rejected, the usual procedure of estimating a combined sample of crisis and non-crisis observations on spreads is not legitimate.

We then turn to the dynamic equations, which we estimate first by using the residual from the long-run equations, in particular a somewhat more parsimonious model reported in Table 1, column 4. The PMG technique is later used to estimate unconstrained short run dynamics and a common long run relationship, but our initial estimates, reported in Table 3, also constrain the short run dynamics to be the same. The 
common short-run dynamics then give some idea of the average effect on spreads across the set of emerging market countries.

Of particular interest to us is to see whether the forecasted stance of US monetary policy, and not just current interest rate variables, helps explain the evolution of emerging market spreads. Therefore, we first attempt to relate our US interest rate variables - the T Bill rate, the 10-year Treasury rate, and the interest rate spread between high and low risk corporate borrowers - to indicators of inflationary pressures and the strength of US economic activity. These are presented in Table 2, where 3 lags of each of the explanatory variables are included in each case. Changes in the latter variables are often cited by "Fed watchers" as leading indicators of changes in Fed policy.

The three interest rate variables are affected differently by movements in these indicators. The T Bill rate seems to respond significantly, and positively, to upticks in retail sales and capacity utilization, while evidence of a significant effect of producer prices and M2 is weaker. Indeed, the latter variable is negative, so that a liquidity effect of monetary expansion may operate. Long-term bonds also respond positively to retail sales, while the first lag of M2 expansion is significantly positive, perhaps reflecting fears of future inflation from an easier monetary policy. Finally, the corporate bond spread does not seem to respond systematically to our set of indicators.

We then proceed to use the predicted values of the forecasting equations of Table 2-and other explanatory variables - in dynamic equations for the emerging market spread. These are reported in Table 3, where all the coefficients, except for the intercepts, are identical across countries. 
Table 2. Forecasting Equations for First Differences in US Interest Rates 1992M5-2004M6

Coefficient values (absolute t-ratios)

\begin{tabular}{|c|c|c|c|}
\hline $\begin{array}{l}\text { Explanatory } \\
\text { variables: changes } \\
\text { in logs of: }\end{array}$ & US Tbills & 10-year Treasuries & $\begin{array}{l}\text { Corporate Hi-Lo } \\
\text { Spread }\end{array}$ \\
\hline \multicolumn{4}{|l|}{ Producer Price } \\
\hline Lag 1 & $2.400(1.29)$ & 4.438 (1.68) & $-4.359(.76)$ \\
\hline Lag 2 & $2.308(1.23)$ & $-2.677(1.01)$ & $4.176(.73)$ \\
\hline Lag 3 & $-2.716(1.48)$ & $-4.973(1.90)$ & .356 (.06) \\
\hline \multicolumn{4}{|l|}{ Retail Sales } \\
\hline Lag 1 & $2.751(1.95)$ & $6.266(3.13)$ & $-9.099(1.62)$ \\
\hline Lag 2 & $5.643(3.84)$ & 6.826 (3.27) & 1.745 (.39) \\
\hline Lag 3 & 2.791 (1.99) & 3.612 (1.81) & $-2.408(.56)$ \\
\hline \multicolumn{4}{|l|}{$\begin{array}{l}\text { Capacity } \\
\text { Utilization }\end{array}$} \\
\hline Lag 1 & $10.124(3.54)$ & $5.524(1.36)$ & $4.291(.49)$ \\
\hline Lag 2 & $3.604(1.24)$ & $.425(.10)$ & $-3.769(.42)$ \\
\hline Lag 3 & $7.128(2.38)$ & $.707(.16)$ & $-11.098(1.21)$ \\
\hline \multicolumn{4}{|l|}{ M2 } \\
\hline Lag 1 & $-3.081(1.37)$ & 8.563 (2.67) & $-12.034(1.74)$ \\
\hline Lag 2 & $-2.082(.96)$ & $-.547(.18)$ & $-1.761(.26)$ \\
\hline Lag 3 & $-3.601(1.57)$ & $1.201(.37)$ & $-3.812(.54)$ \\
\hline Constant & -.0324 & -.1303 & .1163 \\
\hline No. of obs. & 146 & 146 & 146 \\
\hline $\mathbf{R 2}$ & .3418 & .1796 & .068 \\
\hline p-value & .0000 & .0000 & .0000 \\
\hline
\end{tabular}


Table 3. Dynamic Error Correction Models for Changes in Log Spreads: Fixed Effects, Non-crisis periods, 1991M1-2004M6

Coefficient values ${ }^{16}$ (absolute t-ratios)

\begin{tabular}{|c|c|c|c|}
\hline explanatory variables & $\begin{array}{l}\text { Actual US interest } \\
\text { rate changes only } \\
\text { (1) }\end{array}$ & $\begin{array}{l}\text { Actual and forecast } \\
\text { US interest rate } \\
\text { changes (2) }\end{array}$ & $\begin{array}{c}\text { Parsimonious } \\
\text { model } \\
\text { (3) }\end{array}$ \\
\hline $\begin{array}{l}\text { (1) lagged residual from } \\
\text { Column } 4 \text { of Table } 1\end{array}$ & $-.1040(9.33)$ & $-.1037(9.12)$ & $-.1035(9.13)$ \\
\hline \multicolumn{4}{|l|}{$\begin{array}{l}\text { (2) changes in US Interest } \\
\text { Rate Variables }\end{array}$} \\
\hline US T Bills & $.0338(1.66)$ & $.00092(.04)$ &.. \\
\hline 10 year Treasuries & .0653 (3.41) & $.0674(3.46)$ & .0671 (3.66) \\
\hline $\begin{array}{l}\text { US hi-low corporate } \\
\text { spread }\end{array}$ & $.1274(16.9)$ & $.1280(16.6)$ & $.1288(17.0)$ \\
\hline Forecast US T Bills & .. & $.0660(1.36)$ & .0735 (1.96) \\
\hline Forecast 10yr Treasuries & .. & $.0114(.21)$ & .. \\
\hline $\begin{array}{c}\text { Forecast US hi-low } \\
\text { spread }\end{array}$ & .• & $.1619(4.26)$ & $.1513(4.92)$ \\
\hline \multicolumn{4}{|l|}{$\begin{array}{l}\text { (3) changes in country } \\
\text { specific variables }\end{array}$} \\
\hline trade openness & $.1016(.96)$ & $.0982(.93)$ & .. \\
\hline debt/gni & $.00888(2.49)$ & $.00894(2.49)$ & $.00974(2.74)$ \\
\hline reserves/debt & $-.0219(3.35)$ & $-.0220(3.35)$ & $-.0237(3.63)$ \\
\hline short-term/total debt & $-.0281(3.55)$ & $-.0302(3.77)$ & $-.0304(3.81)$ \\
\hline (4) contagion dummy & $.00288(.97)$ & $.00444(1.47)$ &.. \\
\hline \multicolumn{4}{|l|}{ (5) statistics } \\
\hline no. of obs. & 1471 & 1441 & 1443 \\
\hline $\mathbf{R 2}$ & $\begin{array}{c}\text { Within .2218 } \\
\text { Between .3108 } \\
\text { Overall .1960 } \\
\end{array}$ & $\begin{array}{c}\text { Within .2369 } \\
\text { Between .3161 } \\
\text { Overall .2119 } \\
\end{array}$ & $\begin{array}{c}\text { Within .2368 } \\
\text { Between .3080 } \\
\text { Overall .2122 } \\
\end{array}$ \\
\hline $\begin{array}{l}\text { p-value for zero } \\
\text { coefficients }\end{array}$ & .0000 & .0000 & .0000 \\
\hline p-value for test all $u(i)=0$ & .0009 & .0033 & .0038 \\
\hline
\end{tabular}

\footnotetext{
${ }^{16}$ Separate country intercepts are not reported.
} 
The first column of Table 3 reports estimates of a model that includes only the residual from the first-stage regression (from Table 1) and the first differences of the long-run determinants. In the notation of equation (8), the set of $Y$ variables is identical to the $X$ variables. Notable in the results is that the lagged residual is strongly significant, consistent with an error correction model and implying that 10 percent of the deviation from the long-run relationship is closed each month. The short-run dynamics are significantly affected by some of the same variables. In particular, increases in both the US long rate and corporate spread tend to increase the Emerging market spread, as does the country’s debt/gni ratio. Conversely, increases in reserves and the proportion of debt that is short-term tend to lower the spread. Columns 2 and 3 add forecast (one month ahead) US interest rate variables. The forecast change in the hi-low spread and, in the parsimonious model (dropping variables with insignificant coefficients), also the forecast change in the US T Bill rate, tend to increase spreads. Thus, movements in US economic activity and inflation have an indirect effect on emerging market spreads.

The Pooled Mean Group estimates tend to confirm the conclusions derived from the two-step procedure. These results, presented in Table 4, impose the same long-run relationship but allow the short-run dynamics to differ across countries. The common long-run coefficients are given in the upper part of the table. As expected, they have the same signs as those in Table 1: the T Bill rate times debt has a positive (but insignificant) coefficient, the US 10-year rate a negative effect, greater trade openness and reserves reduce the spread, while higher debt increases it. The error-correction term, as captured by the coefficient on the lagged dependent variable, is almost everywhere significant with the right sign. Its median value, around -.15, is somewhat higher in magnitude than that 
Table 4. Pooled-Mean-Group Dynamic Error Correction Models for Changes in Log Spreads: Fixed Effects, Non-crisis periods, 1991M1-2004M6

\section{Coefficient values $^{17}$ (absolute t-ratios)}

\begin{tabular}{|c|c|c|}
\hline Explanatory variables & Full model & Parsimonious model \\
\hline \multicolumn{3}{|l|}{ (1) Long-run coefficients } \\
\hline 10-yr Treasury rate & $-.2301(4.29)$ & $-.2058(4.41)$ \\
\hline $\begin{array}{l}\text { US hi-low corporate } \\
\text { spread }\end{array}$ & $.00585(.29)$ & $.00753(.43)$ \\
\hline $\begin{array}{l}\text { US Tbill rate times } \\
\text { country's debt/gni }\end{array}$ & $.000775(1.80)$ & $.000562(1.48)$ \\
\hline trade openness & $-.4676(1.84)$ & $-.5352(2.27)$ \\
\hline debt/gni & $.00471(1.21)$ & $.00734(2.08)$ \\
\hline reserves/debt & $-.0221(3.40)$ & $-.0225(3.83)$ \\
\hline short-term/total debt & $-.00628(.77)$ & $-.00116(.16)$ \\
\hline \multicolumn{3}{|l|}{$\begin{array}{l}\text { (2) coefficient on lagged } \\
\text { EM spread, by country: }\end{array}$} \\
\hline Argentina & $-.0720(2.08)$ & $-.0577(2.03)$ \\
\hline Brazil & $-.1312(3.28)$ & -.1301 (3.39) \\
\hline Bulgaria & $-.1372(3.00)$ & $-.1362(3.04)$ \\
\hline Colombia & $-.3232(1.92)$ & $-.2851(1.87)$ \\
\hline Ecuador & $-.1286(3.28)$ & $-.1315(3.41)$ \\
\hline Mexico & $-.1699(2.96)$ & $-.1823(3.10)$ \\
\hline Morocco & -.1601 (3.99) & $-.1547(4.14)$ \\
\hline Nigeria & $-.1393(3.93)$ & -.1188 (3.99) \\
\hline Panama & $-.4963(3.50)$ & $-.5228(3.67)$ \\
\hline Peru & $-.4452(3.81)$ & $-.1420(5.11)$ \\
\hline Philippines & $-.1405(2.50)$ & $-.1461(2.91)$ \\
\hline Poland & $-.1545(2.64)$ & $-.1339(2.70)$ \\
\hline Russia & $-.1205(2.74)$ & $-.1254(2.97)$ \\
\hline South Africa & -.0191 (.39) & $-.0157(.37)$ \\
\hline Turkey & $-.3084(1.47)$ & $-.3139(1.98)$ \\
\hline Ukraine & $-.3742(1.76)$ & $-.3420(2.04)$ \\
\hline Venezuela & $-.1321(3.20)$ & -.1345 (3.39) \\
\hline \multicolumn{3}{|l|}{ (3) statistics } \\
\hline no. of obs. & 1443 & 1443 \\
\hline R2 & .3294 & .3194 \\
\hline Adjusted R2 & .2458 & .2703 \\
\hline $\begin{array}{c}\begin{array}{c}\text { p-value for zero } \\
\text { coefficients }\end{array} \\
\end{array}$ & .0000 & .0000 \\
\hline
\end{tabular}

\footnotetext{
${ }^{17}$ Coefficients on the explanatory variables in first-differences and separate constant terms, which are allowed to differ across countries, are not reported.
} 
estimated in Table 3. The short-run dynamic terms captured by coefficients on the $\Delta Y$ variables are too numerous to be reported; they are diverse but include many significant values, including on forecasted US rate variables. The parsimonious model of the rightmost column of the table drops insignificant $\Delta Y$ variables to get more efficient estimates.

\section{Conclusions}

Our results suggest that, in order to understand the effect of global monetary conditions and of an emerging market country's own policies, we need to separate the sample of emerging market spreads into two, distinguishing crisis from non-crisis periods, and need to allow for non-linearity in the effect of US rates on emerging market spreads. Our results confirm the differences between crisis and non-crisis periods, including differences of the effect of US rates, and confirm the existence of non-linearity.

Furthermore, variables capturing anticipation of US monetary policy changes have significant effects on emerging EM spreads, in addition to the current values of US interest rate variables.

What is the prospect for emerging market spreads at present, in 2005 , in the light of expected increases in US interest rates as the very expansionary monetary conditions are brought back to a more neutral position—and perhaps to a tightening stance should US inflation ratchet up? Our framework for analysis suggests some tentative conclusions.

It is useful to consider the question in two stages. First, the level of interest rates in world capital markets—strongly influenced by US rates—will affect the solvency of 
emerging market borrowers. However, if they have moderate levels of debt, their repayment prospects will remain good and there will be little increase in the probability of default, and hence little increase in spreads. For countries that are close to the borderline of solvency, however, global interest rates can have a dramatic impact on the ability to repay, and could lead to a much steeper increase in their spreads. So the situation of each individual emerging market country is crucial to gauging the effect of US monetary tightening. As an illustration, Figure 4 displays the impact a 200-basispoint increase in the U.S. Treasury bill interest rate on emerging market spreads (using the long-run estimates of Table 1, and assuming no change in the long-term rate or corporate spreads): this translates into increases ranging from 6 basis points (for countries with debt-to-GNI ratios below 40 percent) to 64 basis points (for highly indebted countries with debt-to-GNI ratios above 90 percent).

Figure 4 Change in sovereign bond spreads from 200 basis point increase in U.S. interest rates for countries with different indebtedness

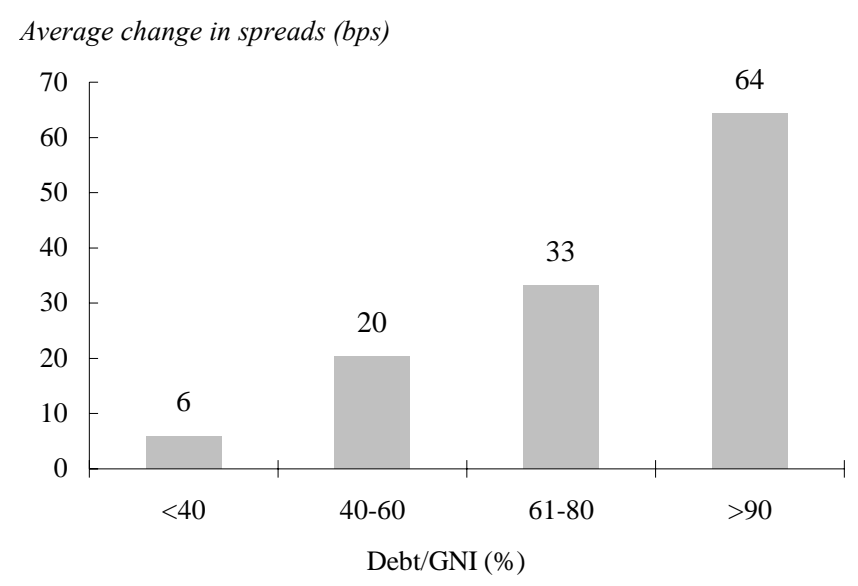

Second, if the tightening of monetary conditions tips a country into a position of default, then it might provoke a more widespread shift towards reduced risk appetite by 
provoking a significant unwillingness of investors in emerging market debt to rollover existing debt or extend new debt—what Calvo calls a "sudden stop.” This has occurred on at least half a dozen occasions over the past two decades, and would correspond in our model to a shift to a crisis equilibrium. While the causes of the crises are many, and there is no consensus that US monetary policy was even an important contributing factor in each of them, the debt crisis of August 1982 and Mexico’s devaluation of 1994 both followed a sharp tightening of US monetary policy, and attacks on Asian currencies in 1997-98 and strain on Argentina's currency board in 2000-2002 came during a period of US dollar strength. Subsequent abandonment of US dollar pegs (de facto or de jure) has no doubt left these emerging market countries less vulnerable to currency crisis.

For a number of reasons it seems to us that the risk that US monetary tightening might lead to dramatic increases in emerging market spreads and in global risk appetite is much lower than in those past periods mentioned above. First, countries' levels of indebtedness are generally lower, as a ratio to GDP, than they were in those earlier periods, as countries have learned the dangers of external borrowing, especially short term, and the level of foreign exchange reserves is also considerably higher. ${ }^{18}$ However, countries are differentially affected by the current high level of commodity prices, some benefiting greatly through their commodity exports, while others may be mainly impacted by the higher value of their oil imports.

Second, the fact that monetary tightening is largely anticipated (which was not the case, for instance, in March 1994) is likely to lead to a less brutal adjustment of spreads and to permit emerging market countries to take palliative measures in the meantime, 
including lengthening maturities to lock in lower rates. For those countries that still limit the fluctuations of their currencies against the US dollar, the fact that the dollar has weakened against the euro and yen gives more room for maneuver.

Finally, there is evidence that investors are much more able to discriminate among borrowers, and less likely to infer that problems in one country signal problems in others. ${ }^{19}$ For instance, the default by Argentina in 2002-the largest default in historydid not cause much disruption in world capital markets, nor did neighboring countries suffer major increases in their spreads. Thus, should higher interest rates push a country to the edge of default, the likelihood of generalized contagion seems much lower.

\footnotetext{
${ }^{18}$ Though aggregate figures are very much influenced by China, India, Korea, and a few other Asian countries.

${ }^{19}$ Masson (2003) found that co-movement of EM spreads was lower in crises subsequent to the Asian crisis, indicating greater differentiation among countries.
} 


\section{Appendix: List of Variables}

\begin{tabular}{|c|c|c|}
\hline variable name & definition & source \\
\hline EM spread & Emerging Market Bond Index & JP Morgan \\
\hline debt/gni & total debt /Gross National Income & GDF, World Bank \\
\hline short-term debt/total debt & GDF, World Bank \\
\hline tradeop & (imports+exports of G\&S)/GDP & IFS, IMF \\
\hline reserves/debt & for. exchange reserves/total debt & GDF, World Bank \\
\hline US long-term interest rate & government 10-year bond yield & US BEA \\
\hline US Tbill rate & secondary market yield, 3-mo. treas. bill & US BEA \\
\hline US hi-low corp. spread & Moody's Baa-Aaa corp. bond yield & US BEA \\
\hline crisis dummy & $=1$ if country in crisis, otherwise 0 & Kaminsky (2003) \\
\hline contagion dummy & =n if n other countries are in crisis & based on Kaminsky (2003) \\
\hline US producer price index & & US BEA \\
\hline US capacity utilization & Industrial sector & US BEA \\
\hline US retail sales & All sectors & US BEA \\
\hline US M2 & & Federal Res. Board \\
\hline & & \\
\hline & & \\
\hline & & \\
\hline & & \\
\hline
\end{tabular}




\section{References}

Boss, M., and M. Scheicher, 2002, “The Determinants of Credit Spread Changes in the Euro Area,” BIS Papers No. 12, Bank of International Settlements, August 2002.

Camerer, Colin F. (1997), "Progress in Behavioral Game Theory,” Journal of Economic Perspectives, 11 (Fall): 167-88.

Colin-Dufresne, P., R. Goldstein, and S. Martin (2001), “ Determinants of Credit Spread Changes.” Journal of Finance 56, pp. 2,177-2,208.

Credit, 2004, Volume 5, Issue 06 (June), pp. 30-31, www.creditmag.com

Duffee, G R (1996), “Treasury Yields and Corporate Bond Credit Spreads: an Empirical Analysis”, Working Paper, Federal Reserve Board.

Duffee, G R (1998), “The Relationship between Treasury Yields and Corporate Bond Yield Spreads”, Journal of Finance, 53(6).

Eaton, Jonathan, and Mark Gersovitz (1981), "Debt with Potential Repudiation: Theoretical and Empirical Analysis,” Review of Economic Studies, 48: 289-309.

Elton,E., M. Gruber , D. Agrawal, and C. Mann, (2001), “ Explaining the Rate Spread on Corporate Bonds”, Journal of Finance 56, pp. 247-277.

Eichengreen, Barry, Andrew Rose, and Charles Wyplosz (1995), "Exchange Market Mayhem: The Antecedents and Aftermath of Speculative Attacks,” Economic Policy.

Eichengreen, Barry and Ashoka Mody, "Lending Booms, Reserves and the Sustainability of Short-term Debt: Inferences from the Pricing of Syndicated Bank Loans," Journal of Development Economics, 63: 5-44.

Ferrucci, Gianluigi (2003), “Empirical Determinants of Emerging Market Countries’ Sovereign Bond Spreads,” Bank of England Working Paper 205.

Ferrucci, Gianluigi, Valerie Herzberg, Farouk Soussa, and Ashley Taylor (2004), "Understanding Capital Flows to Emerging Market Economies," Financial Stability Review, London, June.

Jeanne, Olivier (1997), “Are Currency Crises Self-Fulfilling? A Test, ” Journal of International Economics, 43(November): 263-86

Kaminsky, Graciela (1003), "Varieties of Currency Crisis”, NBER Working Paper 10193, December. 
Kamin, Steven and Karsten von Kleist (1999), “The Evolution and Determinants of Emerging Market Credit Spreads in the 1990s”, International Finance Discussion Papers No. 653, Board of Governors of the Federal Reserve System (November).

Leake, Jeremy (2003), “Credit Spreads on Sterling Corporate Bonds and The Term Structure of UK Interest Rates”, Bank of England Working Paper 202, October.

Longstaff, F A and Schwartz, E. S. (1995), “A Simple Approach to Valuing Risky Fixed and Floating Rate Debt”, The Journal of Finance, 50: 789-820.

Masson, Paul (1999), “Contagion: Macroeconomic Models with Multiple Equilibria,” Journal of International Money and Finance (August).

(2003), “Empirical Regularities in Emerging Market Spreads”, mimeo, Brookings Institution.

(2001), “Multiple Equilibria, Contagion, and the Emerging Market Crises,” in R. Glick, R. Moreno, and M. Spiegel, eds., Financial Crises in Emerging Markets, (Cambridge, UK: Cambridge University Press).

Merton, R. (1974), “On the Pricing of Corporate Debt: The Risk Structure of Investment Rates”, Journal of Finance, 29, pp 449-470.

Min, Hong-Ghi, Duk-Hee Lee, Changi Nam, Myeong-Cheol Park, Sang-Ho Nam (2003), "Determinants of Emerging Market Bond Spreads: Cross-Country Evidence," Global Finance Journal, 14: 271-86.

Morris, Stephen, and Hyun Song Shin (1998), "Unique Equilibrium in a Model of SelfFulfilling Currency Attacks,” American Economic Review, 88(June): 587-97. (2002), "Rethinking Multiple Equilibria in Macroeconomic Modelling,” Macroeconomics Annual (Cambridge, MA: National Bureau of Economic Research).

Pesaran, M. Hashem, Yongcheol Shin, and Ron P. Smith (1999), "Pooled Mean Group Estimation of Dynamic Heterogeneous Panels," Journal of the American Statistical Association 94 (June): 621-34

Uribe, Martin, and Vivian Z. Yue (2003), “Country Spreads and Emerging Countries: Who Drives Whom?” NBER Working Paper No. 10018, October. 